\title{
(Re)Imagining the Church Through the Ordination Liturgy: Towards an Armenian Ressourcement
}

\author{
Arman Gregory Shokhikyan \\ Ph.D., Theology and Religious Studies Department, University of \\ Nottingham, Nottingham, UK \\ frgregoris@gmail.com;arman.shokhikyanı@nottingham.ac.uk
}

\begin{abstract}
This case study of the presbyteral ordination service of the Orthodox Church of Armenia aims to uncover some aspects of the Armenian ecclesiological vision that lie buried under the neoscholastically-framed manuals of theology. By analyzing liturgical texts and comparing them with two theology manuals that are still influential, the paper, in the spirit of ressourcement, challenges the unexamined presuppositions of the handbooks through which ordination liturgy is currently understood. Furthermore, by focusing on the earlier and distinct aspects of the ordination liturgy, the paper excavates some neglected ecclesiological perspectives. In particular, the ressourcement approach allows us to rediscover some pneumatological aspects that can be a valuable theological resource for current ecclesiological discussions.
\end{abstract}

\section{Keywords}

Armenian Orthodox Church - ecclesiology - Holy Spirit - neo-scholasticism ordination - ressourcement

\section{Introduction}

While the theological study of the Church is becoming an increasingly vibrant discourse in the Western world, ${ }^{1}$ an Armenian ecclesiological vision remains

1 Paul Avis (ed.), The Oxford Handbook of Ecclesiology (Oxford: Oxford University Press, 2018), Introduction. 
unexplored. Although there are several works written by modern Armenian authors on ecclesiological issues, none of them explores the understanding of the Church's nature and identity based on the Armenian liturgical experience. This paper aims to remedy that gap. It offers a new examination of the Armenian ecclesiological vision by critically adapting the insights of la nouvelle théologie in conversation with the Armenian liturgical tradition. As a catalyst for the discussion, I will use nature-grace discourse because it plays a key role both in western theological discussions and Armenian theology textbooks. Despite the fact that the nature-grace discussion is a western theological phenomenon, we see a considerable exchange between the ressourcement theologians and Russian Orthodox émigré theologians and philosophers in the twentieth century. ${ }^{2}$ On the Armenian side, while, unfortunately, we cannot trace any significant group exchange with the 'new theologians', the intellectual activity of the Armenian Catholic order of Mkhitar at St. Lazaro island stands out as a prominent example of the ressourcement spirit. ${ }^{3}$

This paper, in line with the ressourcement aspiration of the Mkhitarists, aims to further that conversation by focusing on the Armenian Ordination service and bringing to light the multiple theological levels of the rite. While the Armenian ordination rite of all clerical ranks is an important research field, this paper is confined to the presbyteral ordination service as it is a focal point for diverse liturgical and theological developments. All translations of Armenian liturgical sources and textbooks are mine, otherwise noticed. Before proceeding into the heart of the matter, it is necessary, however, to situate the issue in a broader historical context.

\section{Scholasticism and Its Effect on the Armenian Sacramental Theology}

The western nature-grace discourse has another importance for the Armenian theological horizon because, owing to some late medieval Latin-Armenian

2 Andrew Louth, 'French Ressourcement Theology and Orthodoxy: A Living Mutual Relationship?', in Gabriel Flynn and Paul Murray (eds) Ressourcement: A Movement for Renewal in Twentieth-Century Catholic Theology (New York: Oxford University Press, 2012), pp. 495-507.

3 The Mkhitarists have produced a series of scholarly publications of ancient Armenian versions of otherwise lost ancient Greek Patristic and Liturgical texts and research on classical and modern Armenian language. It would not be an exaggeration to state that the Mkhitarists cultivated the specific Armenian theological vocabulary in the context of Greek and Latin literature. Being a Roman Catholic order did not stand for them as a barrier but rather as a bridge-building between different cultures and even denominations. 
ecclesial reunion, ${ }^{4}$ the scholastic and lately neo-scholastic mentality had a quite significant influence on the Armenian theological thought and has been diffused in the form of theology manuals. This neo-scholastic model of reasoning about sacramental theology transmitted the seven-sacrament system into the Armenian theological perception, starting in the fourteenth century. The seven-sacraments system seems to appear in the Armenian context through the works of Gregory of Tatev, a medieval Armenian scholastic theologian of the fourteenth to the fifteenth centuries. Gregory was an abbot and a teacher of the Tatev abbey school located in the small Armenian kingdom of Syuniq. Owing to a short ecclesial union with the Crusaders during the Cilicia kingdom, many Latin works were translated into Armenian and were discussed and debated by the Armenian theologians. After the fall of the Cilician kingdom, the Armenian-Latin ecclesial and theological relations continue with a certain exchange of ideas. Gregory of Tatev was regarded among the best Armenian theologians of the time, comparable to Aquinas in Europe..$^{5}$ It is also noteworthy that the Union council of Florence (1431-1449) with its decrees on the Armenians explicitly imported the seven-sacrament system into the Armenian theological imagination. ${ }^{6}$

It should be noted that, at the present time, the Armenian historical experience has three theological trajectories going side by side that are as follow:

- Indigenous Armenian Christianity developed during Ani and Cilicia kingdoms from the ninth to the fourteenth centuries.

- Late Medieval scholastic elements entered the Armenian theological imagination during the exchange with the Latin missionaries and remain dominant.

4 Synods of Adana (1307) and Sis (1316) adopted explicitly pro-Latin reforms in the liturgical practices that later were partly abandoned in the Synod of Sis (1371). Vrej Nerses Nersessian, 'Armenian Christianity', in Ken Parry (ed.), Blackwell Companion to Eastern Christianity (Oxford: Wiley Blackwell, 2007), pp. 43-44. See also Armenia and the Crusades: the Chronicle of Mattew of Edessa (Lanham, New York: University Press of America, 1993); T. S. R. Boase (ed.), The Cilician Kingdom of Armenia (Edinburgh: Scottish Academic Press, 1978); Jacob Ghazaryan, The Armenian Kingdom in Cilicia During the Crusades: The Integration of Cilician Armenians with the Latins 1080-1393 (London: Curzon Press, 2000); Robert W. Thomson, "The Crusades through Armenian Eyes', in Angeliki Laiou and Roy P. Mottahedeh (eds), The Crusades from the Perspective of Byzantium and the Muslim World (Washington, D.C: Dumbarton Oaks, 2001), pp. 71-82.

5 The most famous work of Gregory is regarded as being the Book of Questions that has some similarities with Aquinas' Summa Theologiaei: Gregory of Tatev, The Book of Questions (Constantinople, 1729).

6 Bull of Union with the Armenians, November 1439: Jaroslav Pelikan and Valerie Hotchkiss (eds), Creeds \& Confessions of Faith in the Christian Tradition, Volume 1 (New Haven, CT: Yale University Press, 2003), pp. 751-66. 
- A ressourcement movement started by the Armenian Roman Catholic order of Mkhitar which despite its zeal for patristic and liturgical renewal, did not systematically saturate the whole Armenian theological imagination with further conversations accompanied by contemporary Orthodox, Roman Catholic, and Protestant theological sensibilities. ${ }^{7}$

These trajectories were not compared and contrasted but simply coexisted alongside without a critical examination of their relationship. As a result, we observe a conflict between the classical sacramental theology of the textbooks and actual liturgical practices. On the one hand, an Armenian theologian talking about sacramental theology will start with the classical notion of the sacrament as a visible sign of invisible grace. Yet, on the other hand, s/he will immediately be forced to admit that in the Bible, the terms mysterion (Greek) and sacramentum (Latin) refer not to a liturgical rite but to a person, Christ, the Incarnate Word who is alive and present with us in the Spirit. ${ }^{8}$ To continue, almost every Armenian theologian will state that the Armenian Church has seven sacraments. Yet, what Armenians call 'droshm' (seal) has nothing to do with the confirmation rite and it is performed together with baptism. ${ }^{9}$ Hence, the fact that the Armenian tradition does not have the sacrament of confirmation challenges the overall assumption of the seven sacraments system. These simple yet perplexing examples demonstrate certain patterns: we make theological assertions based on classical sacramental theology that contradict the reality of liturgical sources, practices, and patristic writings. It seems that we

7 Besides predominantly (neo) scholastic model of reasoning, the Armenian tradition also had fruitful contacts with the German historical school. In that regard, the Armenian theology did not have a neo-patristic synthesis phenomenon but rather, due to German-Armenian student exchanges, there was a historical-critical awareness that brought to the discoveries of many Armenian and non-Armenian (but preserved in Armenian) patristic sources. This historical sensibility also produced certain ecclesial reform attempts. These attempts were advocated mostly by high-ranking clergy and their attitude towards reform rather than preservation, which demonstrates that traditionalism was not typical of the Armenian clergy. Although that movement did achieve some success, the Genocide and the Soviet period did not allow it to fully take place throughout all Armenian communities. At present, there are diverse approaches and there is an urgent need for a coherent theological vision and a bold ecclesial policy. For more on the Armenian reformation movement see Hacik Gazer, Die Reformbestrebungen in der Armenisch-Apostolischen Kirche im ausgehenden 19 und im ersten Drittel des 20 Jahrhunderts (Göttingen: Vandenhoeck und Ruprecht, 1996).

8 Edward Schillebeeckx, Christ the Sacrament of Encounter with God (London: Sheed \& Ward, 1987).

9 Gabriele Winkler, 'Confirmation or Chrismation? A Study in Comparative Liturgy', Worship 58.1 (1984), pp. 2-17. 'Original Meaning and Implications of the Pre-Baptismal Anointing', Worship 52.1 (1978), pp. 24-45. See also Danielou's notion of sphragis in The Bible and the Liturgy (Michigan: Servant Books, 1979), pp. 54-69. 
have two patterns: one is deeply embedded in the ancient rituals, texts, and symbols of the actual liturgy, while the other has crept in from medieval scholastic theology, which became a turning point in the way that the sacraments were regarded, examined, and comprehended. These two models of reasoning coexist awkwardly, so presenting various theological and pastoral problems. This situation of using scholastic theology to elucidate the sacramental worldview of the Eastern Churches is not peculiar to the Armenian tradition, a tendency that Florovsky following Spengler, called pseudomorphoses..$^{10}$ Hence, the principles and concepts such as seven sacraments, a visible sign of invisible grace, form and matter, institution by Christ, the conditions of validity and efficacy, are not relevant in an exploration of the Eastern liturgical experience and practice. While this contradiction of sacramental theory and practice is not a discovery, the Armenian liturgical theology and practice - unlike the Byzantine tradition - still waits to be fully elucidated. The most recent and influential analysis of the specific principle of the Armenian sacramental theology is that of Daniel Findikyan. ${ }^{11}$ However, while Findikyan compellingly points out the presence of the phrase 'the unfailing word' in the Eastern liturgies as a fresh understanding of the Word-Sacrament relationship, he does not focus on the individual liturgies (baptism, ordination, etc.) and their respective theological perspectives. This paper, with all its limitations, ventures into this process. In particular, it aims to excavate the theology that undergirds the authentic sacramental worldview of the Armenian Church - not a prefabricated epistemological framework that foists preconceived principles and categories upon the life from outside, but the innate theology of the sacraments that is coded into the very fabric of the Armenian Church's liturgical experience and emerges from it. In doing so, the paper aims to explore three related questions:

- How is the current Armenian understanding of priesthood shaped by the nature-grace dichotomy presented by Armenian theology textbooks?

- What kind of fresh vision does the Armenian Ordination service offer when is read in the spirit of ressourcement?

- How does this renewed understanding of Ordination liturgy enrich the Armenian ecclesiological vision in general?

The supernatural grace and pure nature perception that is implicitly present in the phraseology and vocabulary of the manuals leads to a certain

10 Oswald Spengler, The Decline of the West (Oxford: Oxford University Press, 1991), pp. 268-271. Georgi Florovsky, Puti russkogo bogosloviia (Paris: YMCA Press, 1937/1983), p. 49.

11 M. D. Findikyan, 'The Unfailing Word in Eastern Sacramental Prayers', in Maxwell E. Johnson and L. Edward Phillips (eds), Studia Liturgica Diversa: Essays In Honor of Paul F. Bradshaw (Portland, OR: Pastoral Press, 2004), pp. 179-180, 188-189. 
ecclesiological understanding regarding the relationship between the clergy and the lay people. To further this argument, let us have an overview of the ordination liturgy since the manuals draw their respective conclusion not merely from scholasticism but from liturgical sources as well. Let us start with the manuals' perspective.

\section{The Perception of Priesthood as Shaped by the Nature-Grace Divide: The Case of Manual Theologies}

While the Armenian Church had multiple catechesises from the eighteenth to the early twentieth centuries, this paper is confined to two textbooks as representations of this overall trend. These two are of Arshak Ter-Miqelyan's The Christian Doctrine of the Armenian Church, ${ }^{12}$ produced in 1900 for the Eastern Armenians and Shnorq Galustyan's Loci Theologie produced for the Armenian community in Constantinople and published in the late twentieth century (1993). ${ }^{13}$ Thus, these two textbooks represent the western and eastern poles of the Armenian Church at that time. Also, they represent a certain historical time scale: from the very beginning to the end of the twentieth century. Moreover, both of them were republished in this century demonstrating their ongoing influence in the seminary settings. Therefore, these two textbooks are particularly suitable for examination. Let us start with the Armenian Patriarch Shnorq Galustyan..$^{14}$ In his textbook, the Patriarch greatly touches on grace as a theological concept. In particular, he writes: 'In theology, grace is God's spiritual and supernatural gifts that are freely given to humans for our eternal salvation. Grace is the attribute of God as well as Sacraments are. Sacraments are sources through which the divine grace flows to the faithful. ${ }^{15}$ For the Patriarch, grace is regarded as spiritual and supernatural, thus implicitly

12 Arshak Ter-Miqelyan (1864-19o1) was a prominent Armenian lay theologian. After completing his studies in Germany, he taught at many Armenian colleges of Eastern Armenia and has produced a significant amount of scholarly work. Among them, stand out the following: The Armenian Church and the Byzantine Councils (1892), Theological Studies (1893), and The Armenian Apostolic Church and her Sacred Order (1897).

13 Shnorq Galoustyan, Loci Theologie, ed. Gregory Damatyan (Jerusalem, 1993).

14 Archbishop Shnork I Galoustian (1913-1990) was the 82nd Armenian Patriarch of Constantinople, with immense pastoral experience and rigorous intellectual pursuits. He has authored many theological works, all of which were pastorally and liturgically oriented. Among these, stand out the following: The Holy Week (Beirut, 1974), The Principal Feasts (Jerusalem, 1976), Biblical Saints (Istanbul, 1977), Saints of the Christendom (1978), and The Armenian Saints (1978).

15 Shnorq Galoustyan, Loci Theologie, ed. Vagharshak Serobyan (Istanbul, 2nd edn), p. 65. 
assuming that the material and natural are in some sense autonomous, hence not requiring God's intervention. This, of course, is not stated in any explicit manner, but the way in whichn the definition of grace is phrased implies a neo-scholastic understanding. Such terminology is continued with the notion of grace as an attribute of God. While the textbook does not give a detailed and comprehensive elucidation, the phraseology betrays a neo-scholastic framework where grace is regarded as a super-added reality without which a pure nature cannot achieve salvation. ${ }^{16}$ In this way, as David Grumett comments in relation to western scholasticism: '... grace is offered in a specific, extrinsic act of divine giving, similar to the giving of a present to a child by its parents. This conception of an exchange separates the gift of grace from the act of creation, however, apparently denying that the bestowal of life is itself an act of grace and perhaps the greatest act of grace.17

With regard to sacraments, this notion becomes even problematic. One wonders whether, if grace is a super-added reality and sacraments are a kind of channel through which grace is transmitted, this implies a pure nature with a separation/dualism of nature and grace? Interestingly, the textbook does not connect the idea of grace with any natural symbolism but simply begins with grace as God's attribute and immediately moves on its 'super-natural' effects on human beings through the sacraments. Here, neo-scholastically framed theology of grace does not leave any room for the notion that supernatural is (in Henri de Lubac's words) just as 'essential to Christianity as the idea of creation, revelation, the Church or sacrament.' ${ }^{18}$ As de Lubac further observed:

Nature and supernatural find themselves in a way juxtaposed and ... enclosed in one and the same genre, of which they constitute, as it were, two species. Too separate to be truly differentiated, they develop on two parallel, fatally homogeneous planes ... Henceforth, everything is thus conceived in double parts ... And the only intelligible difference drawn between one series and the other consists in the epithet joined to them respectively, the one being the so-called 'natural' and the other 'supernatural'19

16 David Grumett, De Lubac: A Guide for the Perplexed (London: T\&T Clark, 2007), pp. 7-24.

17 David Grumett, De Lubac, p. 15. See also his 'Henri de Lubac: Looking for Books to Read the World', in Flynn, and Murray (eds), Ressourcement, pp. 236-49.

18 Henri de Lubac, A Brief Catechesis on Nature and Grace (San Francisco, CA: Ignatius Press, 1984), p. 9 .

19 Henri de Lubac, 'The Mystery of the Supernatural', in Theology in History (San Francisco, CA: Ignatius Press, 1996), pp. 289-9o. 
This approach unwittingly implies that creation is not a gift in itself but rather a finalised entity with no internal openness to its ultimate source. Here grace is adds something to nature rather than perfects it.

Let us now move to another handbook of theology which was produced in Eastern Armenia at the beginning of the twentieth century by a theologian who was popular that time, Arshak Ter-Miqelyan. Unlike, Patriarch Shnorq, Ter-Miqelyan is much careful in his analysis and bases his arguments on specific quotes from the medieval Armenian authors. However, the structure of his work still highly resonates with the neo-scholastic organization, and specifically the seven-sacraments system. When it comes to grace, Ter-Miqelyan writes, "The grace of the Holy Spirit is deposited in the Church, transmitted through sacraments, and mediated by the minister's blessing and holy anointing (myron).'.20

Both Patriarch Shnorq and Ter-Miqelyan view grace as linked to Holy Spirit as the Spirit's proper function. For both, the place of receiving grace is the Church and the sacraments with clergy as mediators of grace. In particular, with regard to the ordination, Ter-Miqelyan continues, 'For receiving the grace of God it does not matter the dignity and moral merits of the clergy if the faithful receive the holy sacraments by faith. God's grace reaches to faithful even through unworthy minister because what counts is not the minister's personality but his office. ${ }^{21}$

While both Patriarch Shnorq and Ter-Miqelyan regard themselves as articulating and presenting an Armenian Orthodox theology, these passages demonstrate that the framework they are utilizing is not drawn from the Armenian liturgical sources but from a later neo-scholastic sacramental theology of their time. ${ }^{22}$ This, in turn, affects the way that the Armenian theologians or liturgical texts preceding scholastic perception are read and studied: not individually and each in their term but judged primarily on their conformity with the supposed neo-scholastic framework. In contrast to this conceptual framework stands the ordination liturgy to which we now move.

20 Arshak Ter-Mikelyan, The Catechesis of the Holy Church of Armenia, and edn (Vagharshapat: Holy Etchmiadzin, 2007), p. 260.

21 Ter-Mikelyan, The Catechesis, p. 502.

22 This does not mean that they do not quote any Armenian liturgical source, but that these sources are interpreted via neo-scholastic vocabulary. To use Schmemann's terms, manuals do theology of the liturgy and not liturgical theology. 


\section{Reading the Ordination Liturgy}

Overall, the present liturgy is structured around the following units: a. Presentation of the candidates, b. Call-response litany with the approved acclamation, c. Imposition of hands with an episcopal prayer, d. Giving of the stole, e. Liturgy of the Word, f. Vesting, anointing, and naming of the candidate, g. Conferral of the chalice, h. Final blessing prayer followed by the kiss of peace. The ordination rite happens during the Divine Liturgy.

The Armenian Church, unlike the other Eastern Churches, has an anointing of presbyters and bishops. However, unlike the Latin tradition where the presbyter has only hand anointing while the bishop also has an anointing of the forehead, in the Armenian context, a presbyter receives the anointing of both hands and forehead. In the case of the bishop, his forehead and the thumb of his right hand are anointed. We know that the anointing in the Latin Church entered from the imperial anointing before transferring to the clergy. ${ }^{23}$ In the Armenian context, anointing became a widespread practice after the contacts with the Crusaders from the thirteenth century onwards. Before that period anointing was not part of the ordination service, as the oldest, tenth-century Armenian Ordinal does not have it.

The earliest form of the present ordination liturgy is found in the tenth-century Mashtoc (an Armenian analogy to the Greek Euchologion). The structure of the liturgy is straightforward. In contrast to this, the modern presbyteral ordination is an uncritical combination of different manuscripts, ${ }^{24}$ and therefore, presents a mixture of rites than a coherent structure. This edition originates from the nineteenth-century. In this later edition, we see added elements and even some modifications to the basic structure of the earliest Mashtoc such as the blessing of the vestments, anointing of forehead and hands of the candidate, additional readings, and prayers. A comparison of the two versions is shown in the following table:

23 Paul Bradshaw, Rites of Ordination: Their History and Theology (London: SPCK, 2014), pp. 126, 142, 147-48.

24 While the detailed historical development of the Armenian ordination liturgy is a crucial research project and still waits to be done, this paper, due to practical reasons, is confined to the printed sources. 


\section{Ordination service (1oth-century Ordination service (18th-century Missal) \\ Missal)}

- Psalm 130/131

- Divine and heavenly grace

- Invitation to pray for the candidate by a bishop

- Prayer by a bishop

- Biding by a deacon for an ordaining - Blessing of the Vestments bishop and candidate

- Prayer

- Psalm of vesting

- Isaiah 61:1-6 The Spirit of the Lord

- 1 Peter 5:1-4

- Matthew 16:13-19

- Prayer Bishop

- Psalm 130/131

- Vesting

- Psalm of vesting

- Ezek. 33:7-9

- Malachi 2: 5-7

- 1 Peter 5:1-4

- I Tim. 1:12-17
- Candidate/s presentation to the

- Divine and Heavenly grace

- Imposition of the Hands and Prayer

- Isaiah 61:1-6 The Spirit of the Lord

- Luke 4:14-22

- Procession

- Hymn of Holy Spirit

- Anointing and Naming

- Anointing of forehead

- Anointing of hands

- Prayer of Anointing

- Conferral of Chalice

- First Blessing of the New Priest: Peace to you all

- Final Ordination Prayer

- Kiss of Peace (The Divine Liturgy continues)

The later added liturgical unit in the Ordination liturgy opens with the ceremonial procession of the holy oil (mouron), kept in the special dove-shape repository which is brought to the ordaining bishop by another priest/bishop. The bishop takes the repository and starts chanting the first verses of the baptismal hymn. The choir carries forward the rest of the hymn. Next comes the giving of a new name to the candidate and anointing his forehead and hands. Giving a new name to a candidate happens via anointing with the following formula: 'Let it be blessed, anointed and sanctified the forehead/hands of this (new name) priest.' As a response to that, the choir sings: 'Amen, Alleluia (3x), 
with this holy sign, the Gospel book, this holy oil and the feast-day in the name of the Father and the Son and the Holy Spirit. Now and forever and to the ages of ages. ${ }^{25}$ The change of name happens regardless of whether the candidate for ordination is monastic or married. The unit is completed by giving the chalice to the newly ordained with the following formula: 'Receive the authority and capacity from the Holy Spirit to seal and complete the Holy Patarag in the name of our Lord Jesus Christ for sake of living and of the dead. ${ }^{26}$

The ordination liturgy presents us with two liturgical models that have different perspectives on the ordination rite. The first model gives the earliest Mashtoc (Ritual Book) dating to the tenth century, and the other is the eighteenth-century Mashtoc which is in use for ordination liturgy until today. Although having different historical origins, these two models co-exist within the same rite. The difference between them lies not merely in their textual components but in their liturgical focus and perspective. Let us start with the first perspective that resonates with the manuals' framework.

\section{Anointing as Grace: Supernatural Clergy vs. Natural Laity}

The supernatural grace and pure nature perception that is implicitly present in the phraseology and vocabulary of the previously examined manuals leads to a sacred-profane dichotomy in the relationship between the clergy and the lay people. This scholastic understanding of grace has been conflated with the perception of the clergy anointing. In the Armenian imagination and experience, the anointing is linked to baptismal reality and in everyday speech, baptism is referred to more as 'the seal' than anything else. Also, the blessing of the holy oil (myron) that currently happens every seven years, ${ }^{27}$ in the Armenian experience, constitutes a sacred action comparable to a major feast day. However, the anointing of the clergy complicates and confuses the situation as it presupposes that ordination is almost a second baptism. If so, it marks the ordained ones with special gifts that are not accessible to other baptized persons. The extra anointing of the clergy seems to act as a neo-scholastic supernatural, an added reality to the fundamental baptismal anointing of kings and priests. As

25 The Ordination Manual for Clerks, Deacons, and Presbyters (Ejmiacin, 1876), p. 53.

26 Ibid.

27 During the last centuries, the blessing of the myron is the privilege of the Catholicos and it is normally done in September. For more see a trilingual work of Karapet Ter-Mkrtchyan, The Blessing of Holy Myron, 2nd edn (Vagharshapat: Holy Etchmiadzin, 2015). 
a result, clergy are perceived as the depositories of supernatural grace, while the laity as simple recipients of that grace.

Another aspect of this process in the Armenian context was the conflation of the baptismal and ordination imagery. In the later editions of the Missal, the prayers explicitly express more of the baptismal images than the ordination ones. Hence, the candidate is asked to be worthy to be the child of God, a phrase that is used in the Armenian baptismal formula. ${ }^{28}$ Another aspect of this conflation is manifested in the change of the name of the candidate during the anointing. Historically, in the Christian context, name changing happened at baptism or by taking monastic vows that was, again, a baptismal reenactment. However, when the name is changed during the ordination, it becomes an influential theological stimulus that reinforces the ontological difference between the clergy and the laity. In this scenario, a presbyter becomes 'a new' person different from his fellow Christian brothers and sisters. He is not merely their leader or shepherd by a different kind of Christian. Within this model, the clerical ranks of deacon, presbyter, and bishop are imagined in a diametrical progression line of grace and the ordination becomes a 'holy order' through which a recipient obtains supernatural rights and powers: 'The Ordination or Holy Order is the sacrament through which a man is given spiritual power and grace to perform ecclesiastical worship services. The transmission of this power happens through ordination. ${ }^{29}$

In the thought of Galustian, ordination operates as a power sanction and the Holy Spirit acts as a guarantee of that sanction. Also, we do not have deacon, presbyter, and bishop as distinctive Christian ministries in the service of the Church but a general priesthood and clergy the highest of which is the Patriarch. As Ter-Miqelyan observes, 'The Universal Patriarch-Catholicos has the fullness of all graces which he grants to other ministers either by blessing or by order.' ${ }^{30}$ Hence, overall, we observe that both Galustian's and Ter-Miqelyan's theological vocabulary is borrowed from neo-scholastic frameworks and assumptions. These assumptions are not systematic or even consistent, yet, once we follow them on their logic, the implications are about the nature-grace divide, a notion that was criticized by ressourcement theologians like de Lubac and Congar. Furthermore, as we saw, there is symmetry between

28 The formula reads as follows: (name) Servant of God comes to baptism. S/he is baptized in the name of the Father, Son, and Holy Spirit. Having being ransomed through the blood of Christ from the slavery of sin, $\mathrm{s} /$ he becomes a co-heir to Christ, receives an adoption to be a child of the Heavenly Father and a temple of the Holy Spirit. Mashtoc (Vagharshapat: Holy Etchmiadzin, 2001), pp. 16-17.

29 Galoustyan, Loci Theologie, p. 102.

30 Ter-Miqelyan, The Catechesis, pp. 489-49o, 
the later Latin elements in the ordination liturgy and the scholastically framed manuals of Galustian and Ter-Miqelyan. Both of them draw their ordination theology from later Latin liturgical elements such as anointing and authority, not from the earlier Armenian liturgical structure which is the basic skeleton of the rite. Let us now turn to this basic skeleton to see how it imagines the ordination liturgy.

\section{Towards the Theological Imaginary of the Early Mashtoc: The Ministry instead of the Sacerdotes}

If this is the contemporary understanding of the ordination rite, what alternatives do the earliest Mashtoc text can offer us? The liturgy opens with Psalm 130/131 followed by a call-response litany:

Divine and heavenly grace that always fulfills all the ministerial needs of the holy, apostolic Church, calls N. from diaconate to the priesthood for the service of the holy Church according to his testimony and the whole gathered people.

Congregation replies: He is worthy!

Afterward, the ordaining bishop repeats the words of the hymn and adds: 'I put my hand on him and you pray so that he may be worthy to serve before the (table) Almighty Lord with a pure heart and blameless mind.'

Next to the litany, we have the biding of the deacon to pray for the candidate to the priesthood which is concluded by the prayer from the bishop. After the prayer, the liturgy proceeds with the vesting psalm (132) followed by the readings. The Mashtoc puts the first reading of Isaiah 61:1-4. The apostolic reading is 1 Peter 5:1-4 with its exhortation to endure the sufferings for the coming glory. The Gospel reading (Matthew 16:13-19) develops the themes of faith confession and binding-loosing. ${ }^{31}$ The liturgy is concluded by a final prayer. Overall, the ordination liturgy has two episcopal prayers for the candidate. While the first prayer is about listing the tasks of the presbyter such as

31 With regard to the readings, it is notable that the later Mashtoc has a complementary theme of the Holy Spirit in the Messianic age. This Mashtoc puts Luke 4:14-22 that has Jesus quoting Isaiah 61:1-4 advancing the Spirit theme. This is an interesting fact that the latest version of the liturgy while is different from the earliest, yet has an element that supports the earliest reading pattern. This affirms the notion that the latest Mashtoc ordination text is rather a mixed collection of different liturgical manuscripts. 
baptism, Eucharist, healing, and teaching, in the second prayer, the ordaining bishop asks God to grant the candidate with the seven-fold gifts of the Spirit: knowledge, wisdom, understanding, great counsel, might, piety, and the fear of the Lord. ${ }^{32}$

Let us examine theological themes and motives in this simple structure and compared it to the modern editions to see a fuller picture. The Ordination's liturgical call-response hymn that reads as follows is notable:

Divine and heavenly grace that always fulfills all the ministerial needs of the holy, apostolic Church, calls N. from diaconate to the priesthood for the service of the holy Church according to his testimony and the whole gathered people.

Congregation replies: He is worthy!

Afterward, the ordaining bishop repeats the words of the hymn and adds: 'I put my hand on him and you pray so that he may be worthy to serve before the (Table) Almighty Lord with a pure heart and blameless mind.'

Several things are notable here. Firstly, in contrast to the manuals, the ordination liturgy imagines grace differently: grace is linked not with salvation or human nature but with the needs of the church. Grace is not deposited or transmitted through a bishop but fulfills the needs of the ecclesial community and calls a person for filling a particular need of that community. This is not to instrumentalise grace but to stress its redemptive role in the life of the community where clergy are not owners or channels of grace but its equal recipients. It is noteworthy that the same ordination call-response is performed during the diaconal, presbyteral, episcopal, and patriarchal ordinations presenting to be a kind of universal pattern of perception. This leads us to a second note, namely, that based on the litany, a deacon, a presbyter, and a bishop are ministries within the Church and as such correspond to the needs of the Church as a living organism. This vision does not imply a general idea of the priesthood as a sacramental status with a deacon, presbyter, and bishop as its progressive degrees. These three-fold ministries are placed within the community needs and are generated to meet those needs. Hence, the liturgical experience speaks about diverse ministries of a deacon, a presbyter, and a bishop, rather than of general priesthood that is sophistically articulated in the manuals, yet absent from the actual liturgical practice.

32 Gevorg Ter-Vardanyan (ed.), Mayr Mashtoc (Vagharshapat: Holy Etchmiadzin, 2012), pp. 426-430. 
The third aspect we observe in the ordination liturgy is the consent of the congregation with its emphatic axios acclamation. While today in practice this is performed by choir and not by the people, that does not devalue its theological significance, namely, that there is no ministry without the congregation's consent. The axios moment moves our attention to the worthiness of the minister. This notion of worthiness completely makes sense if we understand ministry as fulfilling certain needs of the ecclesial community. A minister is a leader, an example of following Christ, so if s/he does not manifest spiritual integrity, then their ministry does not make sense.

Fourthly, the episcopal exhortation equally deserves careful analysis as it exhibits an interesting vision. Although an ordaining bishop is authorized to put his hands on the candidate, so giving his approval based on examination of the candidate, the final word is given to a prayerful activity of the congregation: '... and you pray so that he may be worthy to serve'. The dignity of the service is not measured by laying of the hands but by prayerful assistance of the people. A candidate is sustained in his ministry through prayers of the congregation, therefore rather than talking about the priestly authority, we are prompt to speak about a triangle when at the top is God and at the bottom angles are the minister and the congregation in a mutual prayerful relationship. This fact is in direct contrast to a neo-scholastic understanding where according to TerMiqelyan's phrase, 'Laying of the hands is the external sign through which by the apostolic succession the grace of God is transmitted to the candidate. ${ }^{33}$ However, as the bishop himself testifies, the validity of the ordination depends not on laying hands of the bishop but on prayers of the congregation, the ordained person is sustained in his ministry due to the prayerful activity of the entire church community. The ordained person is called to a new relationship within the Church as a public servant to the people of God with a specific task-mission. Overall, in the earlier Mashtoc, the liturgical focus of the ordination liturgy seems to be the call-response hymn whereas in the later Mashtoc the central and culminating act is the anointing of the candidate.

\section{From Ordination to an Ecclesial Vision: Spirit and the Church}

Another intriguing aspect of the Armenian ordination liturgy is the explicit references to the Holy Spirit. In many ways, Isaiah's pneumatological reading sets the tone for further developments in different prayers. For instance, in the second prayer, the ordaining bishop asks God to grant the candidate the 
seven-fold gifts of the Spirit: knowledge, wisdom, understanding, great counsel, might, piety, and the fear of the Lord. Next to this prayer, the oldest Missal puts the first reading of Isaiah 61:1-4. The apostolic reading is 1 Peter 5:1-4 with its exhortation to endure the sufferings for the coming glory. Interestingly, while the Gospel reading in the oldest Missal is Matthew 16:13-19, developing the themes of faith confession and binding-loosing, the recent Ordination text has Luke 4:14-22 that has Jesus quoting Isaiah 61:1-4 advancing the Spirit theme. It seems the Isaiah reading with its emphatically Spirit-filled themes emphases the charismatic understanding of the ministry. In this regard, almost a century ago, Conybeare observed that the earlier Armenian ordination manuscripts had a special charismatic ordination of bishops that were not included in the official printed versions. ${ }^{34}$ The excavation of these manuscripts will bring a fresh perspective to the Armenian Ordination liturgies in general. Nevertheless, the last prayer in the oldest Missal is again stressing the charismatic themes:

1. Lord God, mighty and unknowable,

2. God of glory and every honour,

3. You have crowned with glory and honour your saints,

4. You have bestowed a gift of prophecy to human beings.

5. You have given priestly honour.

6. You have chosen holy apostles and within the catholic church crafted the orders of edification for different nations.

7. You have raised in it chief priests,

8. You have planted priests and the ranks of deacons through whom is glorified your coming, Christ our God. And now, Lord, illuminate your servant whom you have chosen and called into priesthood s nd your people... ${ }^{35}$

The prayer starts with mentioning the martyrs (3), moving immediately to charismatic gifts of prophecy, an implicit allusion to Joel 2:28-Acts 2:17: 'I will pour out my spirit upon all flesh; and your sons and your daughters shall prophesy, your old men shall dream dreams, your young men shall see visions' $(\mathrm{KJV})$. The prayer operates within this new age of the Spirit-Pentecost perspective moving from martyric witness to charismatic gifts. In this regard, the priestly honour is placed between the prophetic gifts and the choice of the apostles (4-6). Interestingly, the choosing of the apostles is linked not with the bishops but with enigmatic orders of edification. One is tempted to assume

34 Frederick Cornwallis Conybeare (1856-1924). Rituale Armenorum, being the Administration of the Sacraments and the Breviary Rites of the Armenian Church, together with the Greek Rites of Baptism and Epiphany (Oxford: Clarendon Press, 1905), pp. 231-242. 
that it is about the bishop but the listing of chief priests in the next line simply dismisses this assumption. Most probably, the orders of edification refer to the didascalos, a developed version of which is the Armenian office of the vardapet. ${ }^{36}$ Thus, the priesthood is placed alongside prophetic and apostolic ministry, though there is no idea of the apostolic succession but of apostolic faith. ${ }^{37}$ Priesthood is regarded as a gift of the Spirit to the Church echoing Ephesians 4:11-12: 'And he gave some, apostles; and some, prophets; and some, evangelists; and some, pastors and teachers; For the perfecting of the saints, for the work of the ministry, for the edifying of the body of Christ' (KJV). Priesthood is placed in the context of redemption when the Spirit breathes the gifts to the church. Here the Spirit is imagined as the Giver of gifts, as the liberating Breath of a new creation. This notion of the Spirit as the living breath of the church's life was stressed both by Congar ${ }^{38}$ and Schmemann. In many ways echoing Congar, Schmemann observed deficiencies of ecclesiological systems

36 Afanasyev rightly observed a high role of the didascaloses in the early Church; however, he assumed that they vanished from the third century: Nicholas Afanasyev, The Church of the Holy Spirit, trans. Permyakov (Notre Dame, IN: Notre Dame University Press, 2007), pp. 129-132. Robert Thomson's research on the Armenian vardapets demonstrates that this was not the case and that the early Church didascalos office continued and further developed in the Armenian tradition. For more on the title of vardapet see Robert Thomson's article 'Vardapets in the Early Armenian Church', Le Museon V. LXxv, 3-4, (1962), pp. 367-384. However, Thomson, being not a professional theologian but an Armenologist did not make such a link between the ancient didascalos and the Armenian vardapets, a link which is evident from a comparison of sources and roles. It is noteworthy that this office, though formally, still exists in the Armenian Church practice and is mistakenly confused with the Byzantine notion of an archimandrite. While today the vardapet functionally and formally corresponds to a western canon regular or a canon theologian, historically it is an early Church's charismatic role together with the apostle and the prophet that was developed in Armenian Christianity. Another aspect of it is that the Armenian Church has two vardapet offices: the vardapet and a grand vardapet that correspond to today's masters and doctoral degrees.

37 However, in the recent Ordination rite, a prayer asks the Father for a presbyter candidate to be 'the overseer of the people and co-chair with the apostles': The Ordination Manual for Clerks, Deacons, and Presbyters (Ejmiacin, 1876), p. 39. This latter phrase is an Armenian translation of the Greek $\sigma v v \varepsilon \delta \rho \circ$ (upnnulhg) that implicitly echoes Ignatius' notion of

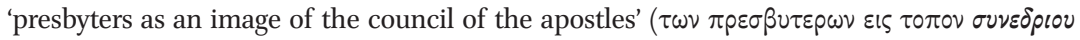
$\tau \omega \nu \alpha \pi \circ \sigma \tau 0 \lambda \omega \nu$ : Magnesians, 6:1). This insight, however, does not imply any notion of a traditional understanding of apostolic succession. As Brent showed, Ignatius' exhortations, rather than being a witness for the power transfer, are 'an iconography expressing the redemptive acts of the triune God'. Allen Brent, 'Culture and Mission in Eastern and Western Catholicism: Can Bishops Represent Cultures rather than Territories?', Sobornost/Eastern Church Review v 34/2 (2012), pp. 16-33, 24-26.

38 Yves M. J. Congar, I believe in the Holy Spirit (New York: Seabury Press, 1983), pp. 192-213, $267-72$. 
of his time pointing out that the reason for that shortage was the neglect of the Holy Spirit in relation to the church:

The doctrine of the Holy Spirit was in many ways cut off from the doctrine of the church ... From being understood as the very life of the church, he came to be seen as a sanction and guarantee. Where authority was stressed as the formative principle of the church, he was presented as a guarantee of that authority. Where individual freedom was stressed against authority, he became the guarantee of such freedom. And finally, having acquired a clearly defined 'function' in the church, he began to be measured ... The wind of Pentecost was duly deposited as the capital of grace to use with caution. ${ }^{39}$

The analysis of the earliest Armenian Ordination prayers shows how deeply charismatic in nature is the earlier Armenian ordination service where grace and gift are used interchangeably. Here Spirit is not a guarantee but freedom and gift. We see that in the earlier service, Spirit is not linked to a sanction of any priestly authority but rather priesthood is one of the Spirit's gifts. It is not about asking God to bless the candidate to have authority for administrating the sacraments, but about joining in the Spirit's work in moulding and forming different ministries for different needs of the Church.

\section{Eucharistic or Spirit Ecclesiology?}

The twentieth century gave us the new and interesting concept of Eucharistic Ecclesiology. Based on the writings of Afanasyev, ${ }^{40}$ de Lubac $^{41}$ and Schmemann, ${ }^{42}$ the notion 'The Eucharist makes the Church'43 became an ideal vision statement for ecclesiological reflection. Zizioulas' seminal work Bishop, Eucharist, Church became a theological leitmotif. ${ }^{44}$ However, while Eucharistic Ecclesiology did generate a fresh perspective in the sacramental theology and ecclesial vision, ${ }^{45}$ in the situation of migration and media

39 Alexander Schmemann, 'Freedom in the Church', in Church, World, Mission: Reflections on Orthodoxy in the West (Crestwood, NY: Saint Vladimir's Seminary Press, 1979), p. 186.

40 Afanasyev, The Church of the Holy Spirit, pp. 129-132.

41 Henri de Lubac, Corpus Mysticum: the Eucharist and the Church in the Middle Ages: Historical Survey (London: scm Press, 2006).

42 Alexander Schmemann, The Eucharist (Crestwood, N.Y: Saint Vladimir's Seminary Press, 1987).

43 Paul McPartlan, The Eucharist Makes the Church: Henri de Lubac and John Zizioulas in Dialogue (Fairfax, VA: Eastern Christian Publications, 2006).

44 John Zizioulas, Eucharist, Bishop, Church: The Unity of the Church in the Divine Eucharist and the Bishop during the First Three Centuries (Brookline, MA: Holy Cross Orthodox Press, 2001).

45 The Eucharist is the source of sacramental life and not simply one of its parts. The bishop is the presider in the eucharistic community, not a supreme ruler. 
communications, it has practically tended to become an episcopal ecclesiology with an emphasis on territory and hierarchy. ${ }^{46}$ On the other hand, in the present age of emigration and media communications, the Spirit ecclesiology seems to be a complementary alternative. It is noteworthy to remember that the same Afanasyev and Schmemann who proposed the idea of Eucharistic ecclesiology, also talk about the Spirit's indispensable role in the nature of the church. As Schmemann reminds, Christians do not confess the church (I/we believe in one, holy, catholic and apostolic church) but the Spirit's role within the church: "And in the Holy Spirit, the Church", such is the earliest form of the third article of the Creed, and it unites - one could almost say it identifies - the Holy Spirit with the Church. But in the course of history, this article was dislocated. ${ }^{47}$ It is noteworthy that the Armenian Creed has a slightly different and lengthier description of the Holy Spirit than the Apostle's or NiceneConstantinople Creeds: '.. . we believe in the Holy Spirit, uncreated and the complete who spoke in the Law, the Prophets, and the Gospels; who descended at the Jordan, proclaimed the Apostle and made a home in the holy ones. And we believe in one, catholic, and apostolic Church'48

To continue the previous line of thought, the Creed links the Church to the Spirit, not to a eucharistic liturgy. The Eucharist even does not appear in the Creed. Interestingly, the Ordination prayers are centered not on the Eucharist itself, but on the Spirit. This perspective challenges the notion of Eucharistic Ecclesiology which, in practice, tends to become an episcopal ecclesiology emphasizing hierarchy and canonical territory. We do not see such a trajectory in the Armenian ordination service where the heart of the liturgy is the charism of the Spirit. And while the Armenian ordination does take place during the eucharistic liturgy and most probably the earliest Ordination Missal shows signs that the ordination prayers are in fact the eucharistic prayers for the ordination day, ${ }^{49}$ nevertheless, the most frequent theme that regularly

46 If the Church is where the Eucharist is celebrated, the bishop takes a central role and the question becomes, With whom are you in communion? And the communion is defined hierarchically, not sacramentally. This was evident in the recent conflict between the Patriarchs of Constantinople and Moscow over the Ukrainian issue. The ex-communication issue followed the logic of the episcopal ecclesiology.

47 Alexander Schmemann, Freedom in the Church, p. 185.

48 The last description of the Spirit's work is immediately followed by the theme of the church which, however, is paused by an additional believe-verb. The same line operates in the Nicene-Constantinople's creed, but is absent from the Apostle's Creed where the church theme immediately follows the Spirit theme without any interruption.

49 Some of these prayers show some Anaphoral structure with an implicit Sanctus. See Mayr Mashtoc, pp. 426-30. 
appears in the ordination service is the Spirit and His/Her ${ }^{50}$ gifts. This is not to devalue the crucial role of the Eucharist in the Church's life but to point out that Eucharistic Ecclesiology is one-sided. On the other hand, the Spiritecclesiology imagines the church as a Pentecost event with diverse gifts of ministry. In this regard, Congar's observations on the relation between charismatic and hierarchical ministries are still relevant:

In the beginning the Church saw itself as subject to the activity of the Spirit and filled with his gifts ... Prophecy declined to some extend in the early Church ... because of an increasing emphasis on the authority of the bishops. This does not imply a contrast between the 'charismatics' and the hierarchical ministries, still less an opposition, since the ministers were themselves were charismatic. ${ }^{51}$

In this regard, a particular interest is the Vatican's 2016 document Iuvenescit Ecclesia. Despite the ecclesiological significance of this topic, the document has been largely unnoticed and is yet to receive detailed academic attention. Iuvenescit Ecclesia presents a developed understanding of the Church as fundamentally dependent upon the charisms, understanding them as co-essential with the (sacramentally grounded) hierarchical gifts. Some initial remarks can be made by way of an Armenian engagement with the document. First, the opening quote from John Chrysostom highly resonates with the Armenian experience of the Spirit who is described as liberating and life-giving: "Through Him we are freed from slavery and called to liberty ... Through the Holy Spirit we see assemblies of priests and we possess ranks of doctors; from this source spring forth gifts of revelation, healing graces, and all of the other charisms that adorn the Church of God. ${ }^{52}$

Secondly, while the document positively stresses the charismatic gifts alongside the hierarchical one, it assumes that the leadership positions in the Church are to be taken primarily by the hierarchy. The charismatic gifts are assumed to be primarily for the lay people and supposed to be discerned by

$5^{\circ}$ Armenian does not have gendered pronouns but for convenience sake and emphasizing the personal nature of the Spirit, the paper uses both pronouns interchangeably.

51 Congar, I believe in the Holy Spirit, p. 65.

52 Congregation for the Doctrine of the Faith, Letter 'Iuvenescit Ecclesia' to the Bishops of the Catholic Church Regarding the Relationship Between Hierarchical and Charismatic Gifts in the Life and the Mission of the Church, 1. http://www.vatican.va/roman_curia/ congregations/cfaith/documents/rc_con_cfaith_doc_20160516_iuvenescit-ecclesia_en.html. For the Armenian description of the Spirit see Divine Liturgy of the Armenian Apostolic Church with Variables, Complete rubrics, and Commentary (London: SPCK, 1984), p. 87. 
pastors. The document does not consider the option of whether the charismatically gifted can be in a leadership position or critique the hierarchy. In this regard, the Armenian Church has to offer the charismatic office of vardapets whose authority was regarded higher than of the ordinary hierarchical orders and who, unlike the hierarchical offices, are addressed as graced with the Spirit (hnqtizinph). Chrysostom's reference to the 'ranks of doctors' is apparently that what the Armenian Church experiences as vardapets. ${ }^{53}$

Finally, although Iuvenescit Ecclesia gives a detailed exposition of the New Testament witness and the Second Vatican Council's documents, it does not provide tangible historical examples of legitimate manifestations of the charismatic ministries in the life of the Church in between the New Testament and contemporary times. In that regard, the Armenian patristic and liturgical traditions give richer resources, which await further rigorous research.

To sum up, this study on the example of the presbyteral ordination service has aimed to uncover some parts of the Armenian ecclesiological vision buried under neo-scholastically framed manuals of theology. By challenging unexamined presuppositions of the manuals through which ordination liturgy was read and understood, the paper focused on the earlier and distinct aspects of the liturgy. This allowed us to see in the liturgical text and action several neglected perspectives. In particular, the ressourcement approach towards the Armenian liturgical tradition helped to rediscover some pneumatological aspects of the Armenian ecclesiological vision that can be a valuable resource in conversation with the current ecclesiological discussions.

53 See Thomson, Vardapets in the Early Armenian Church, pp. 367-384. Based on Thomson's insights, it seems that the ranks of the doctors of Chrysostom and Armenian vardapets are the same reality, i.e., a charismatic ministry alongside the pastoral one (deacon-presbyter/ bishop). 